\title{
Genetic relationship among Labisia pumila (Myrsinaceae) species based on ISSR-PCR
}

\author{
E. Karimi' ${ }^{1}$ H.Z.E. Jaafar ${ }^{1}$, M.A. Aziz ${ }^{2}$, S. Taheri ${ }^{1}$ and R. AzadiGonbad ${ }^{1}$ \\ 'Department of Crop Science, Faculty of Agriculture, University Putra Malaysia, \\ Serdang, Selangor, Malaysia \\ ${ }^{2}$ Agriculture Technology, Faculty of Agriculture, University Putra Malaysia, \\ Serdang, Selangor, Malaysia \\ Corresponding authors: E. Karimi / H.Z.E. Jaapar \\ E-mail: Ehsan_b_karimi@yahoo.com / hawazej@agri.upm.edu.my
}

Genet. Mol. Res. 13 (2): 3301-3309 (2014)

Received January 29, 2013

Accepted August 19, 2013

Published April 29, 2014

DOI http://dx.doi.org/10.4238/2014.April.29.8

\begin{abstract}
The genus Labisia (Myrsinaceae) is a popular medicinal plant in Malaysia. We examined the genetic relationship among three varieties of $L$. pumila var. pumila, L. pumila var. alata, L. pumila var. lanceolata and Labisia paucifolia using an ISSR assay. Fifty-eight primers were tested, among which 18 gave reliable polymorphic banding patterns; these yielded 264 polymorphic markers. A similarity matrix was used to construct a dendrogram, and a principal component plot was developed to examine genetic relationships among varieties. Jaccard's similarity coefficient among species ranged from 0.09 to 0.14 . At a similarity of $0.117 \%$, species were divided into two main clusters. The mean value of the observed number of alleles, the effective number of alleles, mean Nei's gene diversity, and Shannon's information index were $1.98,1.64,0.38$, and 0.57 , respectively.
\end{abstract}

Key words: Genetic relationship; Labisia pumila species; ISSR-PCR 


\section{INTRODUCTION}

Myrsinaceae is a widespread family consisting of 30 genera and about 1000 species of tropical plants, of which about 40 species are medicinal in the Asia-Pacific region, particularly for the treatment of inflammation (Shah et al., 2011). Myrsinaceae are valued for their potential medical compounds, quinones and saponins, with a variety of pharmacological activities. The species of Myrsinaceae are widely distributed throughout the tropics and sub-tropics, but are mainly found in South America and South Africa, Asia, with occurrence extending to Australia, New Zealand, and New Guinea (Stone, 1988). Labisia pumila is a popular herb in Malaysia, where it is locally known as 'kacip fatimah' and mainly used for the production of herbal products. The increase in knowledge on herbal nutraceuticals and health benefits has driven the growth and demand of herbal products (Karimi et al., 2011a).

Genotype identification and genetic mapping have become increasingly important to the documentation of genetic resources and to the protection of plants. Molecular markers have proven to be valuable tools in the characterization and evaluation of genetic diversity within and between species and populations (Guasmi et al., 2012). The commonly used polymerase chain reaction (PCR)-based DNA marker systems are random amplified polymorphic DNA (RAPD), amplified fragment length polymorphism (AFLP) and more recently simple sequence repeats (SSRs) or microsatellites (Gupta and Varshney, 2000; Reddy et al., 2002). The major limitations of these methods are low reproducibility of RAPD, high-cost of AFLP and the need to know the flanking sequences to develop speciesspecific primers for SSR polymorphism. ISSR-PCR is a technique that overcomes most of these limitations (Zietkiewicz et al., 1994; Taheri et al., 2012). ISSR markers have been efficiently used for the study of the genetic diversity of different medicinal plant species and crops such as Phaseolus vulgaris L. (Galván et al., 2003), barley (Yong-Cui et al., 2005), Artemisia capillaries (Shafie et al., 2009), Lippia alba Mill. (Manica-Cattani et al., 2009), Achillea millefolium (Farajpour et al., 2012), Foeniculum vulgare Mill (Bahmani et al., 2012), and Curcuma long (Singh et al., 2012). No report has yet been published on determination of genetic relationships between Labisia pumila species using molecular markers. The objectives of the present study were to determine genetic relationships and identify molecular fingerprints in three varieties of L. pumila var. pumila, alata, lanceolata and Labisia paucifolia using ISSR markers.

\section{MATERIAL AND METHODS}

\section{Source of plant materials}

Seedlings of L. pumila species Labisia paucifolia (SK 1910/10), alata [Stone 6030 (KLU)], pumila [Stone 7233 (KLU)], and lanceolata [(Stone 8385 (KLU)] were respectively collected from the following places of origin: Hulu Langat, Selangor; Sungkai, Perak; and Kota Tinggi, Johore. They were raised in a glasshouse at Field 10, University Agriculture Park, Faculty of Agriculture Glasshouse Complex, Universiti Putra Malaysia $\left(101^{\circ} 44^{\prime} \mathrm{N}\right.$ and $2^{\circ} 58^{\prime} \mathrm{S}, 68 \mathrm{~m}$ above sea level) with a mean atmospheric pressure of $1.013 \mathrm{kPa}$. Healthy and uniform seedlings in terms of leaf numbers were selected for each species. 


\section{DNA extraction}

Total genomic DNA was extracted using the modified CTAB (hexadecyltrimethylammonium bromide) method (Doyle and Doyle, 1987) with some modifications. About 0.1 $\mathrm{g}$ fresh tender leaf tissue was ground in liquid nitrogen and transferred to a $2-\mathrm{mL}$ microcentrifuge tube. To grind the sample, $800 \mu \mathrm{L}$ extraction buffer containing $2 \%$ (w/v) CTAB, $1.4 \mathrm{mM} \mathrm{NaCl}, 100 \mathrm{mM}$ Tris-HCl, $\mathrm{pH}$ 8.0, $20 \mathrm{mM}$ EDTA, 2\% (w/v) PVP and 2\% (v/v) $\beta$-mercaptoethanol were added and the mixure incubated at $65^{\circ} \mathrm{C}$ for $1 \mathrm{~h}$. The sample was extracted with $600 \mu \mathrm{L}$ chloroform:isoamyl alcohol [24:1 (v/v)] and the resultant supernatants were transferred to a new microcentrifuge tube. The air-dried pellet was resuspended in 50 $\mu \mathrm{L}$ TE buffer $10 \mathrm{mM}$ Tris-HCl, $\mathrm{pH}$ 8.0, 1 mM EDTA (pH 8.0) and $2 \mu \mathrm{L}(10 \mu \mathrm{g} / \mathrm{mL}$ ) RNAse. The concentration and purity of isolated DNA was determined using a NanoDrop 2000 spectrophotometer (Thermo Fisher Scientific Inc.) and the quality verified by electrophoresis on a $0.8 \%$ agarose gel. DNA was diluted with sterile distilled water to a concentration of $50 \mathrm{ng} /$ $\mu \mathrm{L}$ for PCR analysis and kept frozen at $-20^{\circ} \mathrm{C}$. DNA samples were stored at $-20^{\circ} \mathrm{C}$ prior to ISSR analysis (Taheri, et al. 2012).

\section{ISSR-PCR analysis}

The ISSR was carried out in a $25-\mu \mathrm{L}$ reaction volume including deionized water, 2X DreamTaq ${ }^{\mathrm{TM}}$ Green PCR Master Mix (Fermentas, International Inc.), with $2 \mu \mathrm{L} 0.6 \mu \mathrm{M}$ oligodeoxynucleotide primer, and $70 \mathrm{ng} / \mu \mathrm{L}$ DNA. All reactions were performed in a thermal cycler (Bio-Rad Laboratories, Inc.) for a total of 40 cycles after an initial denaturation of the template DNA at $94^{\circ} \mathrm{C}$ for $3 \mathrm{~min}$. This was followed by 10 cycles of $94^{\circ} \mathrm{C}$ for $40 \mathrm{~s}$, touch-down one-degree decrement for annealing temperature starting at $7^{\circ} \mathrm{C}$ above $\mathrm{Tm}$ for each primer for $30 \mathrm{~s}$ and $72^{\circ} \mathrm{C}$ for $1 \mathrm{~min}$. This was followed by 30 cycles of $95^{\circ} \mathrm{C}$ for $40 \mathrm{~s}$, with last annealing temperature for $30 \mathrm{~s}$ (Table 1) and $72^{\circ} \mathrm{C}$ for $1 \mathrm{~min}$, and a final extension of $72^{\circ} \mathrm{C}$ for $10 \mathrm{~min}$. The amplification products were separated on a $2 \%$ agarose gel with a $100-b p$ DNA ladder (N3231S, Biolabs, Inc.) at $70 \mathrm{~V}$ for $90 \mathrm{~min}$. The gel was stained with ethidium bromide, visualized under ultraviolet light and photographed with a gel documentation system (Chemillmager $^{\mathrm{TM}}$ Gel Doc., Alpha Innotech Corporation, CA, USA).

\section{Data analysis}

The banding pattern for each primer was scored using the 'UVIDOC' software, and fragment sizes were estimated based on a DNA ladder mix (Fermentas International Inc.). Alleles were designated on the basis of fragment size; bands were scored as diallelic $(1=$ band present, $0=$ band absent). To assess the genetic variation between the different varities of $L$. pumila Benth and L. paucifolia, the eighteen ISSR markers were analyzed using NTSYSpc (Rohlf, 2002). The coefficients of genetic similarity for all pair-wise comparisons were computed using Jaccard's coefficient. A similarity matrix was used to create a dendrogram using the unweighted pair group method with arithmetic mean (UPGMA). The percentages of polymorphic bands (PPB), observed number of alleles $\left(N_{\mathrm{A}}\right)$, effective number of alleles $\left(N_{\mathrm{E}}\right)$, gene diversity (h), and Shannon's information index (I) were calculated with the POPGENE software version 1.31 (Yeh et al., 1997 ) to estimate genetic variation. 


\section{RESULTS AND DISCUSSION}

A total of 58 primers were screened for their ability to amplify genomic DNA in different varieties of L. pumila Benth (alata, pumila, lanceolata) and L. paucifolia (Figure 1), and they are described in Table 1. Forty of these primers amplified no fragments. The remaining eighteen primers generated a total of 268 fragments with an average of 14.9 polymorphic bands per primer (Figure 1).

Table 1. List of ISSR primers and its sequence used for the ISSR analysis.

\begin{tabular}{|c|c|c|c|c|}
\hline No. & Primer Code & Sequence $\left(5^{\prime}-3^{\prime}\right)$ & $\operatorname{Tm}\left({ }^{\circ} \mathrm{C}\right)$ & $\mathrm{Ta}\left({ }^{\circ} \mathrm{C}\right)$ \\
\hline 1 & UBC-808 & $(\mathrm{AG})_{8} \mathrm{C}$ & 54.6 & $61-51$ \\
\hline 2 & UBC_811 & $(\mathrm{GA})_{8} \mathrm{C}$ & 57.2 & $64-54$ \\
\hline 3 & UBC_818 & $(\mathrm{CA})_{8}^{8} \mathrm{G}$ & 57.2 & $64-54$ \\
\hline 4 & UBC 826 & $(\mathrm{AC}) \mathrm{C}$ & 57.2 & $64-54$ \\
\hline 5 & $\mathrm{UBC}^{-} 834$ & $(\mathrm{AG})_{8} \mathrm{YT}$ & 56.5 & $64-54$ \\
\hline 6 & $\mathrm{UBC}^{-} 835$ & $(\mathrm{AG})_{8} \mathrm{YC}$ & 58.8 & $66-56$ \\
\hline 7 & $\mathrm{UBC}^{-} 841$ & $(\mathrm{GA}) \mathrm{Y}$ & 58.8 & $66-56$ \\
\hline 8 & UBC 842 & $(\mathrm{GA})_{8} \mathrm{YG}$ & 58.8 & $66-56$ \\
\hline 9 & UBC 847 & $(\mathrm{CA})_{8} \mathrm{RC}$ & $\begin{array}{l}50.0 \\
58.8\end{array}$ & $66-56$ \\
\hline 10 & $\mathrm{UBC}^{-} 848$ & $(\mathrm{CA})_{8} \mathrm{RG}$ & 58.8 & $66-56$ \\
\hline 11 & UBC_ 850 & $(\mathrm{GT})_{8} \mathrm{YC}$ & 58.8 & $66-56$ \\
\hline 12 & I1 & $(\mathrm{GA})_{9} \mathrm{C}$ & 48.5 & $56-46$ \\
\hline 13 & $\mathrm{I} 2$ & $(\mathrm{GA})_{0} \mathrm{~T}$ & 48.0 & $55-45$ \\
\hline 14 & $\mathrm{I} 3$ & $(\mathrm{GA})_{0} \mathrm{~A}$ & 49.3 & $56-46$ \\
\hline 15 & I7 & (CT) $\mathrm{G}$ & 44.9 & $52-42$ \\
\hline 16 & I74 & $(\mathrm{ACTG})_{4}$ & 54.2 & $61-51$ \\
\hline 17 & CO9-100 & CAGATGGGAGTCAAGTCAAC & 60.4 & $67-57$ \\
\hline 18 & TO5 & CGT(TG) $)_{7}$ & 60.2 & $67-57$ \\
\hline
\end{tabular}

$\mathrm{Y}=(\mathrm{C}, \mathrm{T}) ; \mathrm{R}=(\mathrm{A}, \mathrm{G}) . \mathrm{Tm}=$ melting temperature $\left({ }^{\circ} \mathrm{C}\right) . \mathrm{Ta}=$ anneling temperature $\left({ }^{\circ} \mathrm{C}\right)$.

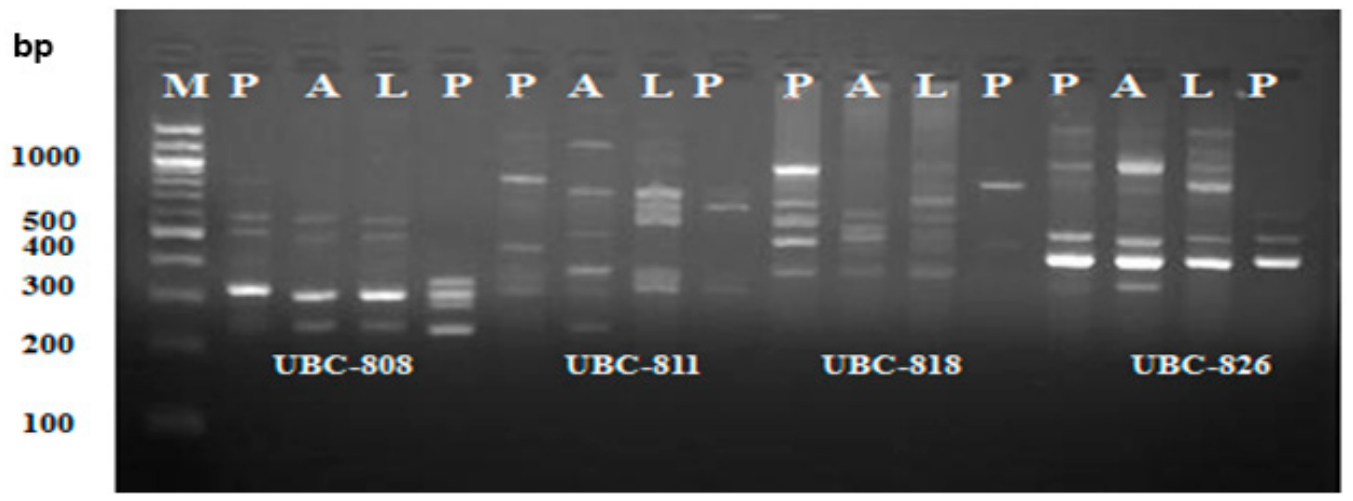

Figure 1. PCR products of genomic DNA from four Labisia pumila species with 18 ISSR primers. Lane $M=100$ bp DNAmarker; lane $P=$ pumila; lane $A=$ alata; lane $L=$ lanceolata; lane $P=L$. paucifolia.

Of 268 fragments produced, 264 polymorphic bands (98.5\%) were used to evaluate genetic relationships between the three varieties of $L$. pumila Benth (alata, pumila, lanceolata) and L. paucifolia (Table 2). The percentage of polymorphism in this study was higher than that reported by previous studies using RAPD (63.4\%) (Rafii et al., 2012) and ISSR (0.73\%) 
analysis (Golkar et al., 2011). The number of alleles varied from 5 (I3) to 25 (I2) fragments per primer and ranged from 160 to $2218 \mathrm{bp}$ in size. In this study, the average number of alleles was higher than that reported by Rafii et al. (2012) in RAPD analysis (1.63) and Singh et al. (2012) for ISSR (1.78) analysis in turmeric. All primers tested revealed polymorphisms between the three varieties of $L$. pumila Benth and L. paucifolia ranging from $83.3 \%$ for primer I3 to $100 \%$ for primers UBC-808, UBC-811, UBC-818, UBC-834, UBC-835, UBC-841, UBC-847, UBC-848, UBC-850, I7, I74, C09-100, and TO5. The effective number of alleles per locus $\left(N_{\mathrm{E}}\right)$ ranged from 1.61 (UBC-850) to 1.76 (UBC-848) with a mean number of 1.64. The difference between the average number of observed alleles and effective number of alleles was due to the uneven frequency of each allele (Babaei et al., 2012). Assuming Hardy-Weinberg equilibrium, the highest mean for Nei's gene diversity (h) was for UBC-841 and UBC-847 $(0.40)$. The average $\mathrm{h}$ in the present study was higher than the calculated Nei's gene diversity of Curcuma long $(\mathrm{h}=0.24)$ (Singh et al., 2012). Shannon's information index (I) ranged from 0.63 (I2) to 0.58 (UBC-808 and UBC-841) with an average of 0.57 , which was higher than that reported in previous studies using ISSR $(I=0.37)$ (Singh et al., 2012). The overall polymorphism (PPB) for the 18 primers across all three varieties of L. pumila Benth and L. paucifolia was $98.5 \%$, suggesting that the ISSR procedure constitutes an alternative approach suitable for examining phylogeny at the DNA level. Jaccard's genetic similarity coefficient varied from species to species.

Table 2. ISSR primer sequences used for analysis ofLabiciapumila species with number of bands amplified, number of polymorphic bands, percentage of polymorphic bands (PPB),product size, observed number of alleles (NA), effective number of alleles (NE), Nei's gene diversity (h), and Shannon's information index (I).

\begin{tabular}{lcccccccc}
\hline Locus & $\begin{array}{c}\text { Total No. of } \\
\text { bands }\end{array}$ & $\begin{array}{c}\text { No. of polymorphic } \\
\text { bands }\end{array}$ & $\begin{array}{c}\text { PPB }(\%) \\
\text { Product size } \\
(\mathrm{bp})\end{array}$ & $N_{\mathrm{A}}$ & $N_{\mathrm{E}}$ & $\mathrm{h}$ & $\mathrm{I}$ \\
\hline UBC-808 & 11 & 11 & 100 & $847-220$ & 2 & 1.67 & 0.39 & 0.58 \\
UBC_811 & 16 & 16 & 100 & $1174-224$ & 2 & 1.62 & 0.38 & 0.57 \\
UBC_818 & 16 & 16 & 100 & $965-362$ & 2 & 1.65 & 0.39 & 0.31 \\
UBC_826 & 13 & 12 & 92.3 & $1517-300$ & 1.92 & 1.64 & 0.55 \\
UBC_834 & 19 & 19 & 100 & $1650-260$ & 2.00 & 1.62 & 0.38 & 0.57 \\
UBC_835 & 16 & 16 & 100 & $1834-226$ & 2.00 & 1.60 & 0.37 & 0.56 \\
UBC_841 & 15 & 15 & 100 & $1543-264$ & 2.00 & 1.65 & 0.40 & 0.58 \\
UBC_842 & 17 & 16 & 94.1 & $790-160$ & 1.94 & 1.62 & 0.38 & 0.55 \\
UBC_847 & 16 & 16 & 100 & $1543-380$ & 2.00 & 1.64 & 0.40 & 0.57 \\
UBC_848 & 16 & 16 & 100 & $987-246$ & 2.00 & 1.76 & 0.38 & 0.57 \\
UBC_850 & 19 & 19 & 100 & $1913-322$ & 2.00 & 1.61 & 0.38 & 0.57 \\
I1 & 11 & 10 & 90.9 & $1400-450$ & 1.90 & 1.63 & 0.36 & 0.53 \\
I2 & 25 & 25 & 100 & $1277-407$ & 2.00 & 1.63 & 0.38 & 0.56 \\
I3 & 6 & 5 & 83.3 & $1200-530$ & 1.80 & 1.63 & 0.38 & 0.56 \\
I7 & 6 & 6 & 100 & $1537-650$ & 2.00 & 1.63 & 0.38 & 0.56 \\
I74 & 12 & 12 & 100 & $2218-240$ & 2.00 & 1.63 & 0.38 & 0.56 \\
CO9-100 & 16 & 16 & 100 & $1853-222$ & 2.00 & 1.63 & 0.38 & 0.56 \\
TO5 & 18 & 18 & 100 & $1017-370$ & 2.00 & 1.63 & 0.38 & 0.56 \\
Total & 268 & 264 & & & & & \\
Mean & 14.9 & 14.6 & 98.5 & & $1.98 \pm 0.12$ & $1.64 \pm 0.15$ & $0.38 \pm 0.06$ & $0.57 \pm 0.08$ \\
\hline
\end{tabular}

The similarity matrix (Table 3 ) indicated that the lowest genetic similarity (0.06) was between L. pumila var. pumila and L. pumila var. alata, and the highest similarity (0.14) was between $L$. pumila var. lanceolata and L. paucifolia. A comparable wide range in similarity values had also been observed between cyclamen accessions (Naderi et al., 2009).

UPGMA cluster analysis of Jaccard's similarity coefficient was employed to observe 
the genetic relationship between the three varieties of $L$. pumila Benth and L. paucifolia. According to the dendrogram constructed using ISSR markers, at the similarity level of 0.117 , the species were divided into two main clusters (Figure 2). In group I, L. pumila var pumila was separated from the other species with only 0.09 similarity. On the other hand, L. paucifolia, $L$. pumila var. lanceolata, and L. pumila var. alata were assigned to group II. L. paucifolia and $L$. pumila var. lanceolata showed the most similarity $(0.14)$ and formed the first subcluster in group II. The lone species $L$. pumila var. alata showed a JSI $=0.118$ with $L$. paucifolia and $L$. pumila var. lanceolata, and formed the second subcluster in group II. Different hierarchical positions in the dendrogram of the three varieties of $L$. pumila Benth and L. paucifolia studied showed that genomes of each variety are not exactly the same. It is imperative to differentiate between L. pumila (Myrsinaceae) species in terms of their physical and chemical characteristics as well as biological activity. For instance, the shape of the petiole base in L. pumila var. pumila and L. pumila var. alata is marginate and winged, respectively, but long in L. pumila var. lanceolata and L. paucifolia (Stone, 1988). Additionally, a previous study on chemical profiling demonstrated that $L$. pumila var. pumila had higher total flavonoids compared to L. pumila var. alata, L. pumila var. lanceolata, and L. paucifolia., while L. pumila var. alata contained higher total phenolics and antioxidant activities compared to the other species mentioned (Karimi et al., 2011b).

\section{Table 3. Genetic similarity indices between each pair of the four Labisia pumila species based on ISSR analysis.}

\begin{tabular}{lllll}
\hline Species & L. pumila & L. alata & L. lanceolata & L.paucifolia \\
\hline L. pumila & 1.00 & & & \\
L. alata & 0.0639535 & 1.00 & 1.00 \\
L. lanceolata & 0.1079545 & 0.1288344 & 0.1357143 & 1.00 \\
L.paucifolia & 0.0972222 & 0.1136364 & \\
\hline
\end{tabular}

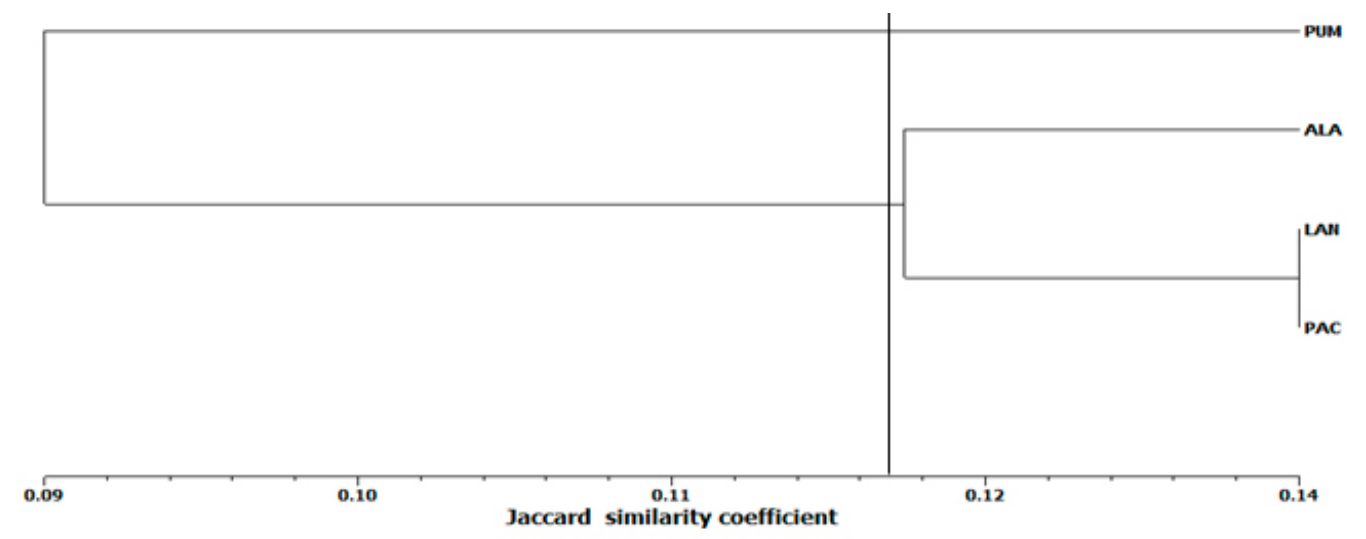

Figure 2. Dendrogram demonstrating the relationships among the four Labisia pumila species based on ISSRs.

Group constellations were also independently developed by using principal component analysis (PCA) to verify the grouping obtained through the dendrogram. PCA further helped in depicting the variation between the three varieties of L. pumila Benth and L. pauci- 
folia in a three-dimensional mode. The first two PCA axes of the mentioned species are shown in Figure 3. PCA divided the Labisia species into two groups, a result similar to the dendrogram derived by UPGMA. Three principal components with eigenvalues greater than unity extracted a cumulative of $78.5 \%$ of the variance in three varieties of $L$. pumila Benth and $L$. paucifolia. The three components, PC1, PC2, and PC3 showed 33.1, 23.4, and 21.9\% variation, respectively. PCA showed the three-dimensional relationships that describe portions of the genetic variance in a dataset for three varieties L. pumila Benth and L. paucifolia.

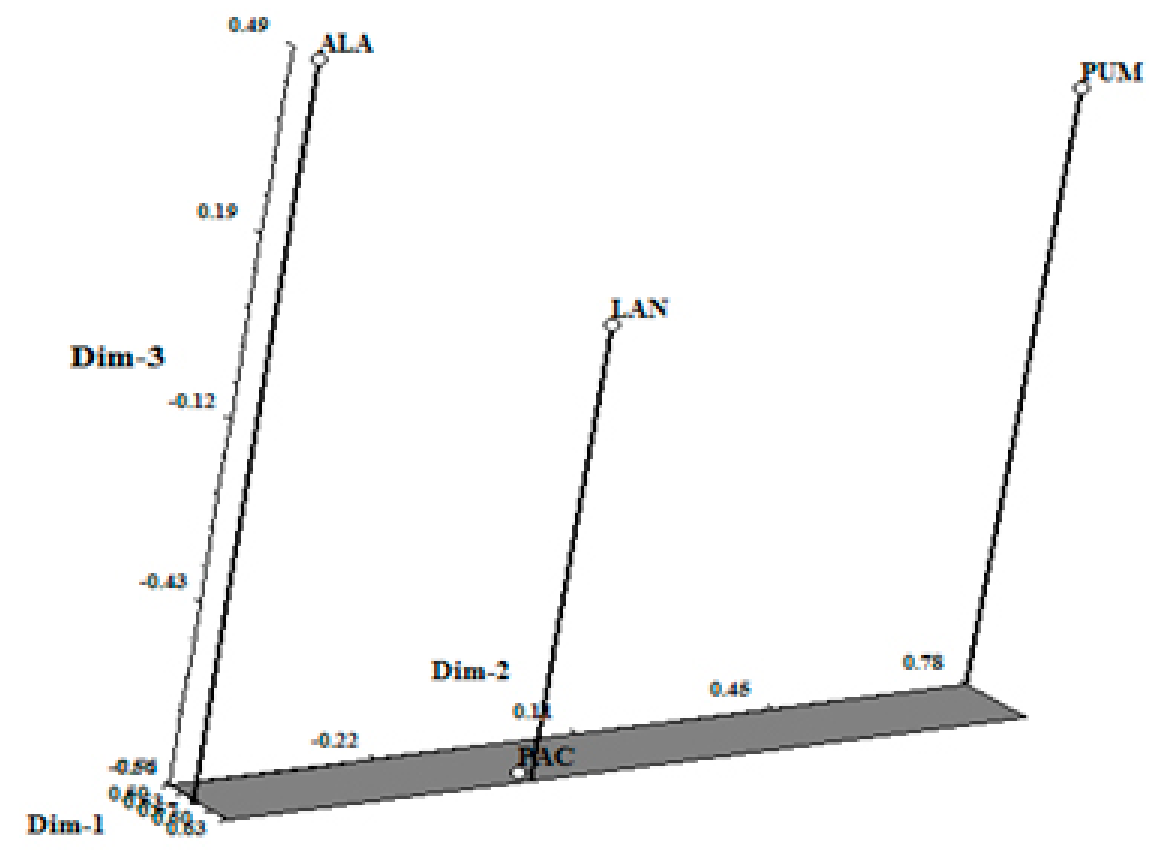

Figure 3. Principal component analysis map for ISSR markers of the four Labisia pumila species.

Although there are published reports on the use of ISSR molecular marker techniques to analyze various species, there is no report on the use of molecular markers in L. pumila Benth. There is a significant need to develop a molecular marker system to address the many unresolved questions related to the genetic history, status, and trends for L. pumila species. For major crop plants, the many advantages of microsatellites make them the preferred marker for genetic studies (Agarwal et al., 2008; Kalia et al., 2011). However, a PCR-derived marker, such as ISSR, that uses non-specific primers, is the most suitable for most wild plant species, such as L. pumila species, due to the lack of locus-specific genetic sequence information (Nybom and Bartish, 2000). Thus, ISSR markers were utilized because they are relatively inexpensive, have modest equipment requirements, and are reliable when good scientific practices are rigorously applied (Skroch and Nienhuis, 1995). On the basis of our results, we believe that an ISSR marker system could be used extensively as a practical and reliable genetic tool for the strategic genetic conservation of L. pumila species. 


\section{CONCLUSION}

This is the first attempt to use molecular markers to investigate genetic relationships of $L$. pumila species, and the information generated herein may be useful for the improvement of this crop and could guarantee a promising future for breeding programs. Further studies examining SSR loci could explain more completely the diversity between these species.

\section{REFERENCES}

Agarwal M, Shrivastava N and Padh H (2008). Advances in molecular marker techniques and their applications in plant sciences. Plant Cell Rep. 27: 617-631.

Babaei N, Abdullah NA, Saleh G and Abdullah TL (2012). Isolation and characterization of microsatellite markers and analysis of genetic variability in Curculigo latifolia Dryand. Mol. Biol. Rep. 39: 9869-9877.

Bahmani K, Izadi-Darbandi A, Jafari AA, Noori SAS, et al. (2012). Assessment of genetic diversity in iranian fennels using ISSR markers. J. Agric. Sci. 4: 79-84.

Doyle JJ and Doyle JL (1987). A rapid DNA isolation procedure for small quantities of fresh leaf tissue. Phytochem. Bull. 19: $11-15$.

Farajpour M, Ebrahimi M, Amiri R, Golzari R, et al. (2012). Assessment of genetic diversity in Achillea millefolium accessions from Iran using ISSR marker. Biochem. Syst. Ecol. 43: 73-79.

Galván MZ, Bornet B, Balatti PA and Branchard M (2003). Inter simple sequence repeat (ISSR) markers as a tool for the assessment of both genetic diversity and gene pool origin in common bean (Phaseolus vulgaris L.). Euphytica 132: 297-301.

Golkar P, Arzani A and Rezaei AM (2011). Genetic Variation in Safflower (Carthamus tinctorious L.) for Seed QualityRelated Traits and Inter-Simple Sequence Repeat (ISSR) Markers. Int. J. Mol. Sci. 12: 2664-2677.

Guasmi F, Elfalleh W, Hannachi H, Feres K, et al. (2012). The use of ISSR and RAPD markers for genetic diversity among south tunisian barley. Int. Scholarly Res. Netw. Agronomy 1: 1-10.

Gupta PK and Varshney RK (2000). The development and use of microsatellite markers for genetic analysis and plant breeding with emphasis on bread wheat. Euphytica 113: 163-185.

Kalia RK, Rai MK, Kalia S, Singh R, et al. (2011). Microsatellite markers: an overview of the recent progress in plants. Euphytica 177: 309-334.

Karimi E, Jaafar HZE and Ahmad S (2011a). Phenolics and flavonoids profiling and antioxidant activity of three varieties of Malaysian indigenous medicinal herb Labisia pumila Benth. J. Med. Plant Res. 5: 1200-1206.

Karimi E, Jaafar HZ and Ahmad S (2011b). Phytochemical analysis and antimicrobial activities of methanolic extracts of leaf, stem and root from different varieties of Labisa pumila Benth. Molecules 16: 4438-4450.

Manica-Cattani MF, Zacaria J, Pauletti G, Atti-Serafini L, et al. (2009). Genetic variation among South Brazilian accessions of Lippia alba Mill. (Verbenaceae) detected by ISSR and RAPD markers. Braz. J. Biol. 69: 375-380.

Naderi R, Alaey M, Khalighi A, Hassani ME, et al. (2009). Inter- and intra-specific genetic diversity among cyclamen accessions investigated by RAPD markers. Sci. Hort. 122: 658-661.

Nybom H and Bartish IV (2000). Effects of life history traits and sampling strategies on genetic diversity estimates obtained with RAPD markers in plants. Perspect. Plant Ecol. Evol. Syst. 3: 93-114.

Rafii MY, Shabanimofrad M, Puteri Edaroyati MW and Latif MA (2012). Analysis of the genetic diversity of physic nut, Jatropha curcas L. accessions using RAPD markers. Mol. Biol. Rep. 39: 6505-6511.

Reddy MP, Sarla N and Siddiq EA (2002). Inter simple sequence repeat (ISSR) polymorphism and its application in plant breeding. Euphytica 128: 9-17.

Rohlf F (2002). NTSYS-pc Numerical Taxonomy and Multivariate Analysis System. Version 2.01. Exeter Publishing Ltd., Setauket.

Shafie MSB, Hasan SMZ and Shah RM (2009). Study of genetic variability of Wormwood capillary (Artemisia capillaris) using inter simple sequence repeat (ISSR) in Pahang region, Malaysia. Plant Omics J. 2: 127-134.

Shah BN, Seth AK and Maheshwari KM (2011). A review on medicinal plants as a source of anti-inflammatory agents. J. Med. Plant Res. 5: 101-115.

Singh S, Panda MK and Nayak S (2012). Evaluation of genetic diversity in turmeric (Curcuma longa L.) using RAPD and ISSR markers. Ind. Crops Prod. 37: 284-291.

Skroch P and Nienhuis J (1995). Impact of scoring error and reproducibility RAPD data on RAPD based estimates of genetic-distance. Theor. Appl. Genet. 91: 1086-1091. 
Stone BC (1988). Notes on the genus Labisia Lindl. Malayan Nat. J. 42: 43-51.

Taheri S, Abdullah TL, Abdullah NA and Ahmad Z (2012). Genetic relationships among five varieties of Curcuma alismatifolia (Zingiberaceae) based on ISSR markers. Genet. Mol. Res. 11: 3069-3076.

Yeh FC, Yang R, Boyle TBJ, Ye Z, et al (1997). POPGENE, the User-Friendly Shareware for Population Genetic Analysis. Molecular Biology and Biotechnology Centre, University of Alberta, Canada.

Yong-Cui H, Ze-Hong Y, Yu-Ming W and You-Liang Z (2005). Genetic diversity in barley from west China based on RAPD and ISSR analysis. Barley Genet. Newsl. 35: 9-22.

Zietkiewicz E, Rafalski A and Labuda D (1994). Genome fingerprinting by simple sequence repeat (SSR)-anchored polymerase chain reaction amplification. Genomics 20: 176-183. 